\title{
Characterization of elaborated Moroccan mullite to improving porous refractories quality
}

\section{(Caracterização de elaborada mulita marroquina para a melhoria da qualidade de refratários)}

\author{
C. Sadik ${ }^{1}$ A. Al Albizane ${ }^{1}$, I. El Amrani ${ }^{2}$ \\ ${ }^{1}$ Department of Chemistry, Faculty of Science and Technology, University Hassan II, \\ Mohammedia-Casablanca, Morocco \\ ${ }^{2}$ Scientific Institute, Department of Earth Sciences, University Mohammed V Agdal, Rabat, Morocco \\ schawki37@gmail.com
}

\begin{abstract}
Production of porous and light-weight bricks with acceptable flexural strength is accomplished. Sawdust was used as an additive to an earthenware brick to produce the pores. SEM-EDS, XRD and XRF analysis of the raw materials and the elaborated refractory were performed. Mixtures containing sawdust were prepared at different proportions (up to $30 \%$ ). Apparent porosity at $1600{ }^{\circ} \mathrm{C}$ was investigated with the bulk density, water absorption, firing shrinkage and flexural strength. Microstructural investigation was carried out by both natural light microscopy and polarized light microscopy. The results obtained showed that the samples tested here maintained their shape without undergoing any deformation up to $1600{ }^{\circ} \mathrm{C}$. The use of sawdust decreased the fired density of the bricks down to $1.24 \mathrm{~g} / \mathrm{cm}^{3}$.
\end{abstract}

Keywords: moroccan mullite, porous refractories, porosity.

\section{Resumo}

Foi conseguida a produção de tijolos porosos e leves de aceitável resistência â flexão. Foi usado residuo de serragem como aditivo para a produção de poros em tijolos. Foram feitas análises de MEV-EDS, DRX e FRX das matérias-primas e do refratário. As misturas contendo os resíduos foram preparadas em diferentes proporções (até 30\%). A porosidade aparente a $1600{ }^{\circ} \mathrm{C}$ foi investigada por avaliação de densidade, absorção de água, retração sob aquecimento e resistência a flexão. Investigação microestrutural foi feita por microscopia de luz natural e microscopia de luz polarizada. Os resultados mostram que as amostras testadas mantiveram a forma sem sofrer qualquer deformação até $1600{ }^{\circ} \mathrm{C}$. $\mathrm{O}$ uso de resíduo de serragem diminuiu a densidade dos tijolos para $1,24 \mathrm{~g} / \mathrm{cm}^{3}$.

Palavra-chave: mulita marroquina, tijolos porosos, porosidade.

\section{INTRODUCTION}

Refractories could be classified into two categories depending on the porosity present in it namely dense and porous refractories [1]. Dense refractories contain porosity in the range $15-20 \%$. These refractories were used in contact with hot liquid metal and gases. Porous firebricks constitute one of the refractory groups which are most commonly used today for heat insulation in industrial applications. They are lightweight refractories that have much lower thermal conductivity and heat capacity than other refractories [2]. Different types of porous firebricks are mainly manufactured by using the raw materials such as diatomite, perlite, expanded vermiculite, calcium silicate, fireclay, kaolin, Silicon Carbide, quartz, alumina and lightweight refractory aggregates by conventional methods [2-4]. Porosity is usually created by adding a combustible material to the raw material mixture. During firing, the combustible material burns out, and leaves a large fraction of pores within the fired body. Different types of pore-formers such as sawdust, foam polystyrene, fine coke, binders and organic foams, or granular materials such as hollow microspheres and bubble alumina are commonly used to obtain decreased density or to produce porous bodies in the insulating material $[2,3]$. Insulating firebricks that have a highly porous structure (between $45 \%$ and $90 \%$ porosity) exhibit low thermal conductivity values [1]. The thermal conductivity not only depends on their total porosity, but also their pore size and shape, chemical and mineralogical composition [2-4].

Many research studies have been conducted, until now, on mullite $\left(3 \mathrm{Al}_{2} \mathrm{O}_{3}-2 \mathrm{SiO}_{2}\right)$ as a mineral phase with many properties: low thermal expansion and conductivity, excellent creep resistance, high temperature strength, and good chemical stability. These studies have focused on their synthesis methods, theirphase equilibrium, their microstructures and their thermo-mechanical properties. Different types of mullitecan be synthesized according to 
the nature of the raw materials and the used process [5-9]. The application fields of mullite are multiple and depend on the properties of each type. In fact, the performance of a refractory (good resistance of heat and thermal shock) is directly relatedto its texture and its richness in mullite.

In this study, porous firebricks have been developed by adding recycled refractory wastes and sawdust to mixture containing different types of Moroccan silica-alumina geomaterials (kaolin clay, red clay and silica sand).

\section{EXPERIMENTAL PROCEDURE}

\section{Materials}

Kaolin clay $(\operatorname{ArgK})$ was selected as the clay raw material for high refractoriness of the products. This clay results from hydrothermal alteration of alkali granite of Oulmès, located in the center of the Moroccan Meseta $[12,13]$. Red Clay (ArgS) is a very fine-grained silt of lower Cretaceousage, rich in clay minerals and poor in carbonates. Very large outcrops of these clay deposits exist in the region of Safi. Clays of this region are intensely exploited by the industrial ceramists for the manufacture of bricks and tiles [13, 14]. Silica Sand (SabM) used in this study comes from an artisanal quarry, located at $3 \mathrm{~km}$ SE of the MechraaHammadi Dam. The sands appear as a thin layer of a white-pink and friable rock, belonging to the series of limestone of the upper Jurassic [13].

Brick raw material obtained from a brick manufacturer (Super Cerame) in Kenitra, Morocco, was used. The contamination level ofsilica-alumina refractory materials used as coatings in kilns in the ceramics industry is low. It is for this reason that fire brick having undergone three years of use as a coatingin a kiln was finely milled to obtain a white powder "AR", and that contains $71.14 \%$ of alumina. Mineralogical analysis of this powder shows that it consists mainly of mullite.

The main components of wood sawdust are hemicellulose, cellulose, and lignin, and these components are decomposed at different temperature ranges. Sizes of the sawdust used in this study were between 1 and $2 \mathrm{~mm}$.

The chemical compositions of the geomaterials, performed by X-Ray Fluorescence (XRF), are shown in Table I.

The mineralogical composition of ArgK consists mainly on kaolinite and small quantities of quartz and illite (Fig. 1). The following mineralogical phases were identified for the red clay (ArgS): illite as the principal mineral, with kaolinite and quartz. Other secondary minerals phases found in this clay are hematite and dolomite [13].

Procedure for brick production Initially, raw materials were dried at $100{ }^{\circ} \mathrm{C}$ in oven. Then, they were powdered by a disc mill. The granulated powder mixtures were uniaxially compacted in hydraulic press under $30 \mathrm{MPa}$ for the rectangular-shaped specimens $(10 \mathrm{~cm} \times 5 \mathrm{~cm} \times 1 \mathrm{~cm})$. The pressed specimens were held overnight by drying at $105^{\circ} \mathrm{C}$ for $24 \mathrm{~h}$ in an oven. Dried specimens were fired in a laboratory-type electrical furnace at the rate of $5{ }^{\circ} \mathrm{C} / \mathrm{min}$ until $1600^{\circ} \mathrm{C}$ (calcination at $600^{\circ} \mathrm{C}$ for $1 \mathrm{~h}$ ). Technological parameters values were measured after firing steps.

Table I - Chemical compositions by XRF of the geomaterials used in this study (wt.\%). (Chemical analysis were performed in laboratories UATRS, CNRST „Morocco in 2012).

[Tabela I - Composições químicas (pesp\%) dos geomateriais usados neste estudo.]

\begin{tabular}{cccccccccccc}
\hline & $\mathrm{SiO}_{2}$ & $\mathrm{TiO}$ & $\mathrm{Al}_{2} \mathrm{O}_{3}$ & $\mathrm{Fe}_{2} \mathrm{O}_{3}$ & $\mathrm{MgO}$ & $\mathrm{CaO}$ & $\mathrm{Na}_{2} \mathrm{O}$ & $\mathrm{K}_{2} \mathrm{O}$ & $\mathrm{P}_{2} \mathrm{O}_{5}$ & $\mathrm{CL}$ & Total \\
\hline $\operatorname{ArgK}$ & $\underline{57.20}$ & 0,0 & $\underline{29.40}$ & 4.50 & 0.65 & 0.26 & 1.55 & $\underline{3.08}$ & 0.00 & 3.28 & 100.00 \\
& & 8 & & & & & & & & & \\
$\mathrm{ArgS}$ & $\underline{51.60}$ & 1.0 & $\underline{19.20}$ & $\underline{9.00}$ & 5.36 & 0.90 & 0.58 & 3.89 & 0.23 & 8.16 & 99.98 \\
& & & & & & & & & & \\
$\mathrm{SaBM}$ & $\underline{96.06}$ & 0.1 & 2.22 & 0.51 & 0.17 & 0.09 & 0.06 & 0.20 & 0.02 & 0.49 & 99.97 \\
& & 5 & & & & & & & & & \\
\hline
\end{tabular}

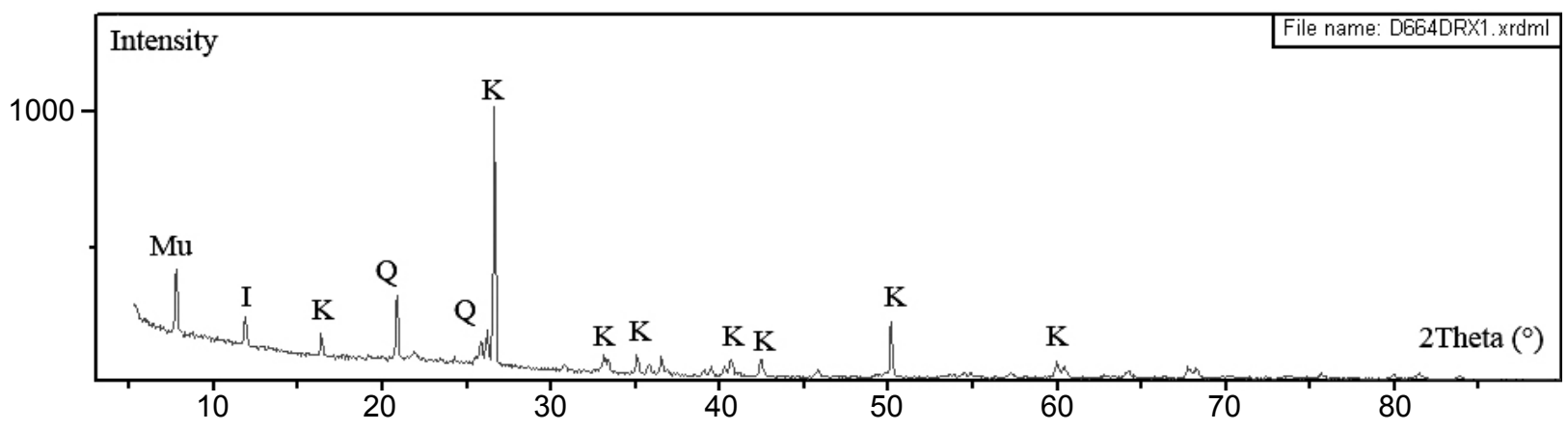

Figure 1: XRD pattern of Oulmès kaolin clay (ArgK). K: Kaolinite, I: Illite, Q: Quartz, Mu: Muscovite. [Figura 1: Difratograma de raios X da argila caulim (ArgK) Olmès. K: caulinita, Q: quatzo, Mu: muscovita.] 


\section{RESULTS AND DISCUSSION}

Fired sample containing only clay and refractory waste mixture

Refractory waste was used to increase the refractoriness of the product by reducing the amount of glassy phase in the structure. In the previous study by the same authors [13], a formula of composition M (40\% ArgK + 15\% $\mathrm{ArgS}+5 \% \mathrm{SabM}+40 \% \mathrm{AR}$ ) has allowed obtaining a good quality of refractory at $1600{ }^{\circ} \mathrm{C}$. A detailed XRD of sample (without sawdust) showed the presence of mullite, cristobalite and quartz (Fig. 2). This sample presents a very good dimensional stability and good mechanical characteristics (Table II). The resistance towards sulfuric acid was checked according to NF EN 993 - 16 standards dealing with dense shaped refractory products [15]. The relative mass reduction after acid treatment is $1.2 \%$. The SEM micrograph of Fig. 3 clearly shows the mullite phase identified by its needle like shape. The sample shows a homogeneous microstructure and especially richness in very fine needles of mullite.
Fired samples containing clay and refractory waste mixtures with sawdust addition

Test results of the bricks

In the second phase of this study we added $10 \%, 20 \%$ and $30 \%$ of sawdust at the mixture M. It was observed that the color of the brick does not change with increasing the amount of sawdust additions. Experimental results of the sample with sawdust additive are given in Table II. The apparent porosity values of fired samples ranged from 9.8 to $71.9 \%$. Bulk density of the product with $0 \%$ and $30 \%$ of sawdust showed a reduction of $42.32 \%$. Shaping (pressing) direction of the brick and the shape of the pores affect the mechanical strength. Depending on the increase in the sawdust addition and porosity content, the resistance values of the samples progressively decreased from 71.4 to 31.4 $\mathrm{MPa}$. The tests were performed according to the procedures recommended by (ASTM) [16-18].

\section{Microstructural analysis of the bricks}

The observation of refractory sample under a binocular microscope identifies some traces related to

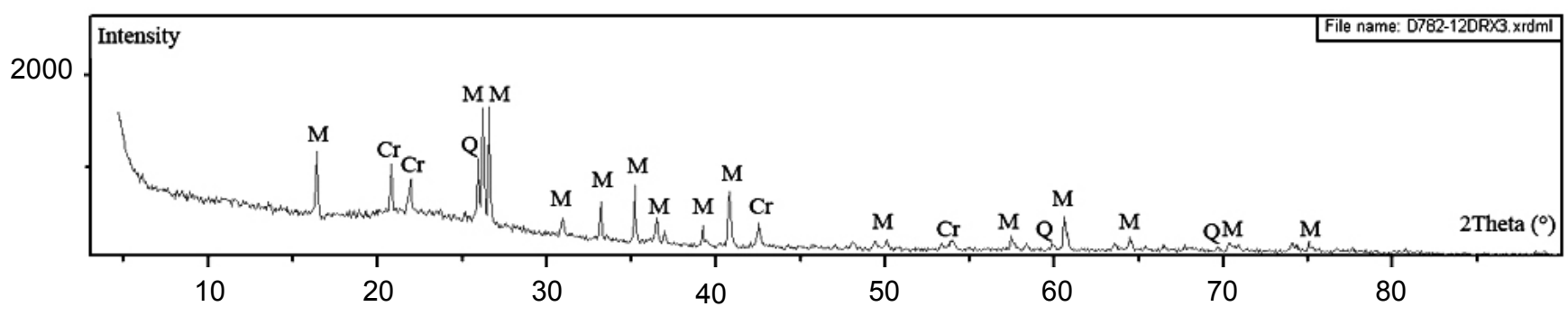

Figure 2: X-ray diffraction pattern of the brick manufactured from mixture $\mathrm{M}$ and fired at $1600{ }^{\circ} \mathrm{C}$ [13]. [Figura 2: Difratograma de raios $X$ do tijolo manufaturado com a mistura M e calcinado a $1600^{\circ} \mathrm{C}$ [13].]
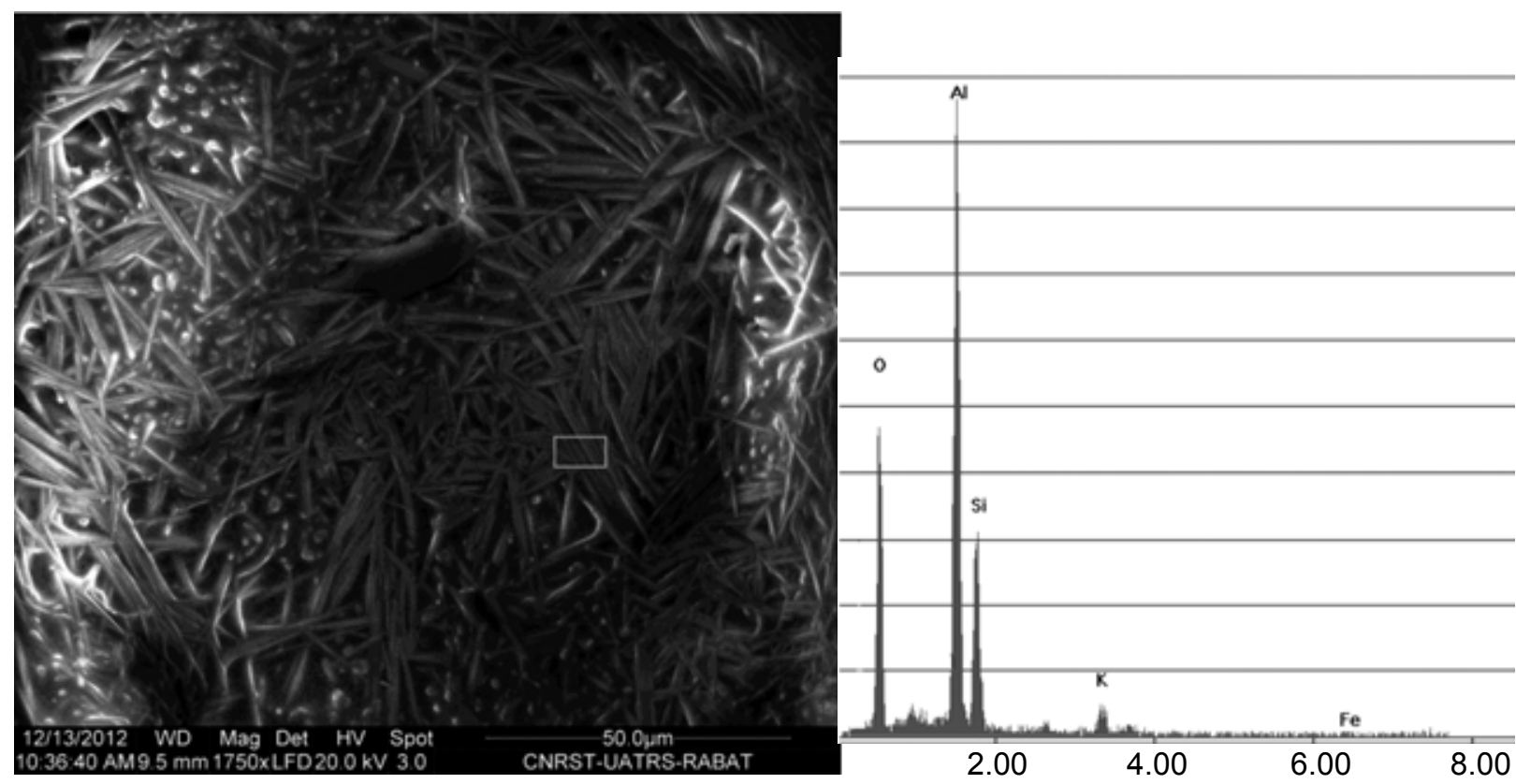

Figure 3: a) SEM microphotography of firebrick; b) EDX analysis of the area indicated by a blue rectangle [13]. [Figura 3: a) microfotografia MEV do tijolo queimado; b) análise EDX da área indicada pelo retângulo azul [13].] 
Table II - Technological test results of the brick without and with sawdust addition fired at $1600{ }^{\circ} \mathrm{C}$.

[Tabela II - Resultados de testes tecnológicos do tijolo com e sem resíduo de serragem queimado a $1600{ }^{\circ} \mathrm{C}$.]

\begin{tabular}{lcccc}
\hline Physical proprieties & Mass & ratio of & sawdust & addition \\
\cline { 2 - 5 } & $0 \%$ & $10 \%$ & $20 \%$ & $30 \%$ \\
\hline Bulk density (g/cm ${ }^{3}$ ) ASTM C373-88 & 2.15 & 1.93 & 1.61 & 1.24 \\
Apparent porosity (\%) ASTM C373-88 & 9.8 & 57.3 & 67.1 & 71.9 \\
Water absorption (\%) ASTM C373-88 & 6.2 & 35.3 & 41.6 & 55.2 \\
Shrinkage (\%) ASTM C326-03 & 5.5 & 5.7 & 5.8 & 6.2 \\
Flexual Strength (MPa) & 71.41 & 49.8 & 41.9 & 31.4 \\
\hline
\end{tabular}

the manufacturing technique, the characteristics of the briquette, and the size and color of inclusions and pores. The observation of the samples was performed using a binocular microscope Olympus-SZX9 with a camera (DS Camera Head DS-5M). The microstructural analysis revealed a higher

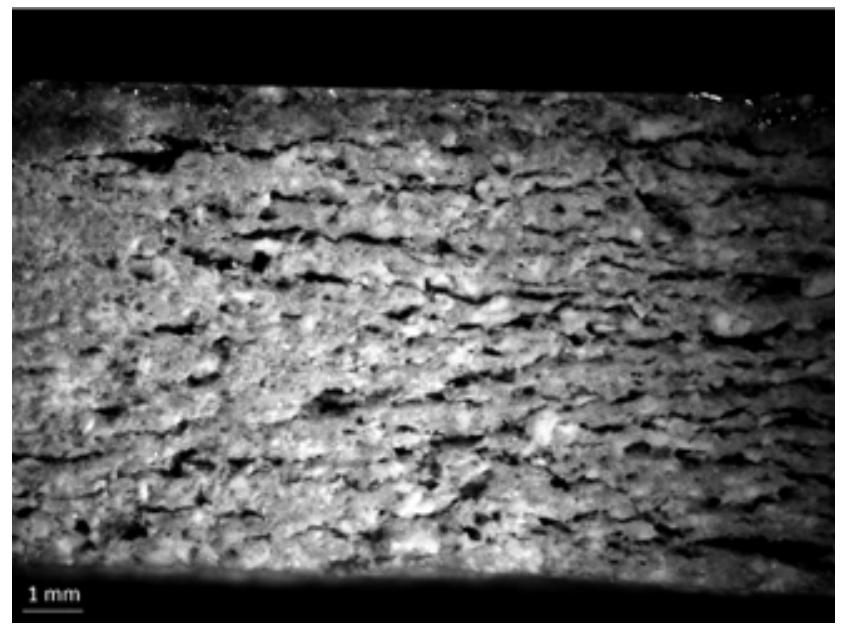

Figure 4: Binocular observation showing the highly porous structure of the firebrick with $30 \%$ of sawdust addition.

[Figura 4: Observação binocular mostrando a altamente porosa estrutura do tijolo queimado com $30 \%$ de adição de resíduo de serragem.]

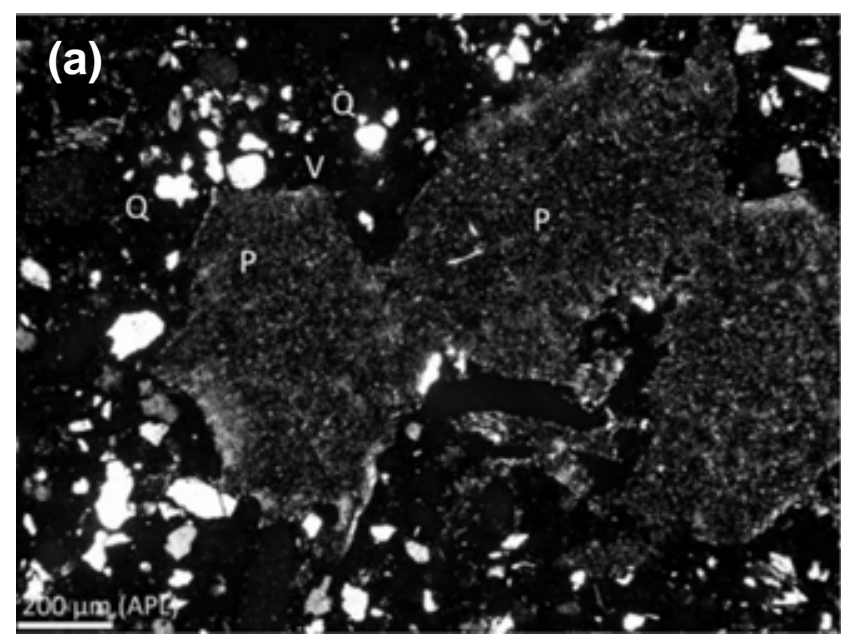

porosity in the briquettes containing sawdust. In addition, the porosity increases with sawdust content. As it can be seen in Fig. 4, the large sized of porosity is about $2-3 \mathrm{~mm}$. Micropores less than $0.1 \mathrm{~mm}$ existed in the fired structure. The pores are often independent and they are in the form of parallel sheets.

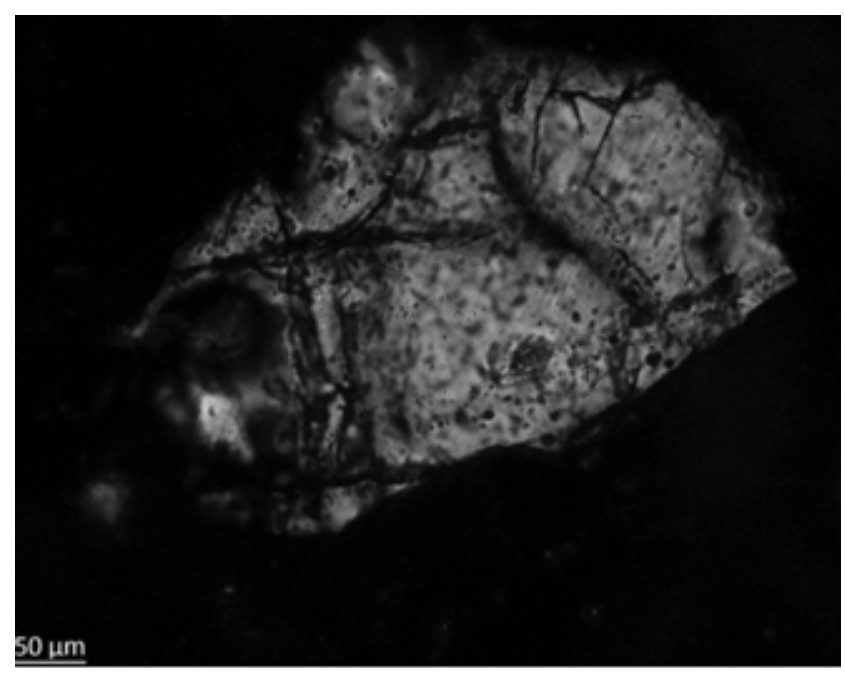

Figure 6: Xenomorphic quartz crystals.

[Figura 6: Cristais de quartzo xenomórficos.]

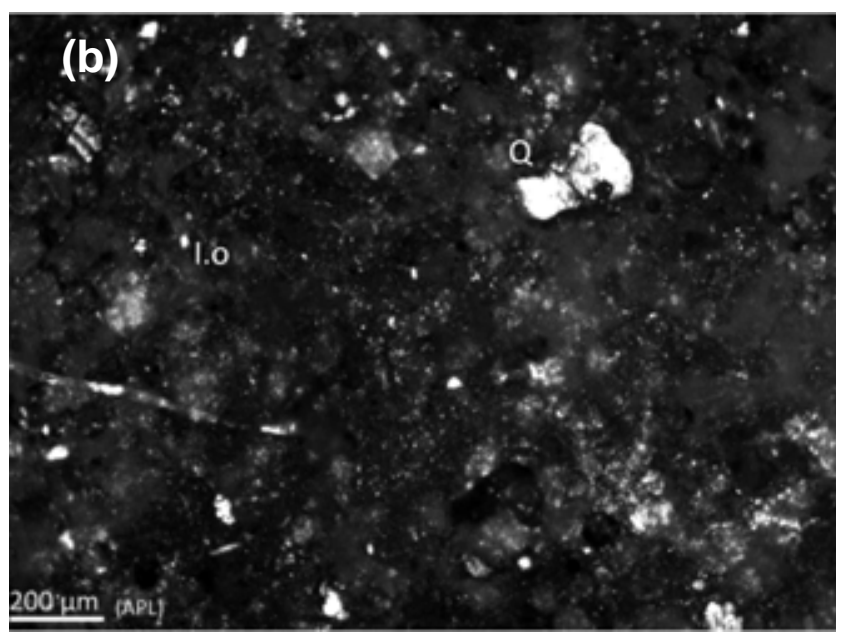

Figure 5: Microstructural analysis of the brick. P: Porosity, I.o: Iron oxide, Q: Quartz, V: Vitreous phase. [Figura 5: Análise microestrutural do tijolo. P: porosidade, I.o: óxido de ferro, Q: quatzo. V: fase vitrea.] 


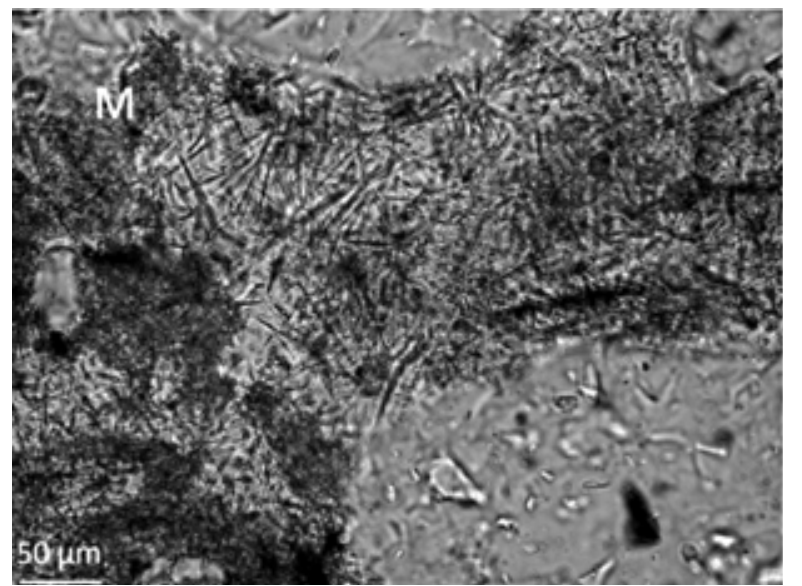

Figure 7: Micrograph showing the shape and abundance of mullite crystals invading the vitreous bottom of the firebrick (PL).

[Figura 7: Micrografia mostrando oformato e a abundância de cristais de mulita invadindo o fundo vitreo do tijolo queimado.]

So, the effect of sawdust addition was obviously observed from the microstructure.

For more details on the nature of the mineral phases and microstructure of briquettes fired at $1600{ }^{\circ} \mathrm{C}$, we use the polarized microscope, generally used for petrographic study of natural rocks. For this, we started by making thin sections of approximately $30 \mu \mathrm{m}$ of thickness in brick fragments. These thin sections have been observed under a microscope Olympus BX 51TF. Fig. 5 illustrates the microscopic observations of fired brick with $30 \%$ of sawdust using both natural and polarized light (AL and APL). The studied material appears heterogeneous with some anisotropic crystals, opaque phases, amorphous areas and porosity. The porosity shows a random distribution and the pore diameters vary between 800 and $1000 \mu \mathrm{m}$. The opaque phases are frequently iron oxides. The anisotropic minerals correspond to quartz crystals which are xenomorphic, show a rolling extinction and are often cracked (Fig. 6). The bottom of the firebrick, mainly composed of amorphous phases, is invaded by microscopic needles of mullite (Fig.7).

\section{CONCLUSION}

The production of porous and lightweight ceramics refractories from mixtures of different Moroccan geomaterials (kaolin clay, red clay, silica sand), recycled refractories waste and sawdust addition was investigated. It was concluded that the sawdust could be used as a suitable alternative raw material source for production of porous refractory due to their organic content. Results indicated that porosity varied between $9.8 \%$ in the brick without sawdust and $71.9 \%$ in the brick that contained $30 \%$ of sawdust. Their fired densities varied between 2.15 and $1.24 \mathrm{~g} / \mathrm{cm}^{3}$, which correspond to a decrease of $42.32 \%$. Depending on the increase in the sawdust addition and porosity content, flexural strength of the samples decreased. Several elements were observed using natural and polarized light microscopy. The most important of these were pores, vitreous phase and quartz, besides mullite crystals formed at elevated temperature.

\section{ACKNOWLEDGEMENT}

This study was conducted in the laboratory of Geomaterials and Geoenvironment (Geo M\&E) of the Scientific Institute (University Mohammed V-Agdal, Rabat, Morocco). The authors acknowledge support from National Center for Scientific and Technical Research (CNRST) (Research Unite URAC 46) and Hassan II Academy for Sciences and Techniques (Project V2GV). Authors would like to thank "Super Cerame" Company for supplying the waste of refractory bricks.

\section{REFERENCES}

[1] S. Banerjee, "Properties of Refractories in Refractories Handbook", Ed. Charles A. Schacht, Schacht Consult. Serv. Pittsburgh, PA, USA (2004).

[2] M. Sutcu, S. Akkurt, Ceram. Int. 35 (2009) 2625-2631.

[3] M. Sutcu, S. Akkurt, A. Bayram, U. Uluca, Ceram. Int. 38 (2012) 1033-1041.

[4] X. Wu, H. Ma, X. Chen, Z. Li and J. Li, New J. Glass. Ceram. 3 (2013) 43-47.

[5] M. A. Sainz, F. J. Serrano, J. M. Amigo, J. Bastida, A. Caballero, J. Eur. Ceram Soc. 20 (2000) 403-412.

[6] M. A. Sainz, F. J. Serrano, J. Bastidab, A. Caballero, J. Eur. Ceram. Soc. 17 (1997) 1277-1284.

[7] W. Brostow, T. Datashvili, J. Geodakyan, J. Lou, J. Mater. Sci. 46 (2011) 2445-2455.

[8] D. N. Boccaccini, E. Kamseu, T. D. Volkov-husović, M. Cannio, M. Romagnoli, P. Veronesi, C. Leonelli, I. Dlouhy, A. R. Boccaccini, Metalurgija (2007) 65-70.

[9] C. Baudin, M.P. Villar, J. Eur. Ceram Soc. 22 (2002) 26472655.

[10] W. Pichor, A. Janiec, Ceram Int. 35 (2009) 527-530.

[11] U. Bulut, J. Sci. 23 (2010) 305-313.

[12] C. Sadik, I. El Amrani, A. Albizane, J. Chem. Chem. Eng. 7 (2013) 132-136.

[13] C. Sadik, I. El Amrani, A. Albizan, New J. Glass. Ceram. 3 (2013) 59-66.

[14] C. Sadik, I.El Amrani et A. Albizane, MATEC Web. Conf. 2 (2012) 01016

[15] BS EN 993-16, "Methods of Test for Dense Shaped Refractory Products. Determination of Resistance to SulphuricAcide" (1995).

[16] ASTM C 326-03, "Standard test method for drying and firing shrinkages of ceramic whiteware clays", Vol. 15-02, Glass and Ceramic.

[17] ASTM C373-88, Standard test method for water absorption, bulk density, apparent porosity, and apparent specific gravity of fired white ware products, Vol. 15-02, Glass and Ceramic.

[18] ASTM C674-88, Standard test methods for flexural properties of ceramic white ware materials, Vol. 15-02, Glass and Ceramic.

(Rec. 14/05/2013, Ac. 11/06/2013) 